\title{
Bacterial Pneumonia at King Abdulaziz University Hospital: A Comparison between Hospital- and Community-Acquired
}

\author{
Daad H. Akbar Maimona M. Ahmad Ahmed T. Altahawi \\ King Abdulaziz University Hospital, Jeddah, Kingdom of Saudi Arabia
}

\section{Key Words}

Pneumonia, hospital-acquired, community-acquired - Causative organisms . Treatment $\cdot$ Mortality

\section{Abstract}

Objectives: To compare community- and hospital-acquired pneumonia (CAP, HAP) with respect to causative organisms, antimicrobial susceptibility, mortality and risk factors associated with high mortality. Methods: From March 1998 to December 1999, the medical charts of patients at King Abdulaziz University Hospital older than 14 years of age with a diagnosis of pneumonia were reviewed. The following data regarding the patient's age, sex, type of pneumonia, admission to intensive care unit (ICU), type of organism isolated, antibiotic susceptibility, outcome, presence of hypotension, tachycardia, tachypnea, disturbed level of consciousness, and renal failure were recorded.
\end{abstract}

\begin{tabular}{ll}
\hline KARGER & ( ) 2001 S. Karger AG, Basel \\
1011-7571/00/0094-0249\$17.50/0 \\
$\begin{array}{l}\text { Fax +4161306 1234 } \\
\begin{array}{l}\text { E-Mail karger@karger.ch } \\
\text { www.karger.com }\end{array}\end{array}$ & $\begin{array}{l}\text { Accessible online at: } \\
\text { www.karger.com/journals/mpp }\end{array}$
\end{tabular}

Results: A total of 324 patients were studied (248 HAP, 76 CAP). Haemophilus influenzae, Moraxella catarrhalis and Streptococcus pneumoniae were the commonest isolates in CAP, while Pseudomonas spp. and Enterobacter spp. were more common in HAP. Pathogens isolated from CAP were more susceptible to ampicillin, co-amoxiclav, ciprofloxacin, cefuroxime, tetracycline and erythromycin, whereas isolates of HAP showed more sensitivity to aminoglycosides and imipenem. Mortality was higher in HAP compared to CAP: 50 versus $21 \%$, respectively $(p<0.001)$. Risk factors associated with high mortality were a more advanced age, tachycardia, hypotension, a disturbed level of consciousness, renal failure and ICU admission. Conclusion: Older less expensive antibiotics can still be used in the treatment of both CAP and HAP, while the newer more expensive antibiotics should be kept in reserve to prevent the development of resistance.

Copyright @ 2001 S. Karger AG, Basel

\author{
Dr. Daad H. Akbar \\ Associate Professor/Consultant Physician \\ PO Box 18298, Jeddah, 21415 (Kingdom of Saudi Arabia) \\ Tel. 9662 6586516/6557043, Fax 96626541626
}

E-Mail daabakb@yahoo.com 


\section{Introduction}

Infectious diseases contribute significantly to patient morbidity and mortality: pneumonia is the sixth leading cause of death in industrialized countries [1, 2]. In the long-term care setting, infection of the respiratory tract is the leading cause of hospitalization and mortality [3]. The costs associated with pneumonia are staggering. It is not only the cost of treatment, but also the economic impact of days lost at work [4, 5]. Knowledge of the prevalence of the organisms within a community and their resistance patterns are important to guide the initiation of empiric treatment. The aim of this study was to compare hospital- and community-acquired pneumonia (HAP and CAP) at King Abdulaziz University Hospital with regard to its causative organisms, antibiotic susceptibility, risk factors associated with high mortality, and mortality.

\section{Method}

From March 1998 to December 1999, the medical charts of patients at King Abdulaziz University Hospital over the age of 14 years were reviewed. Diagnosis of pneumonia was made according to the American Thoracic Society criteria [6]. Sputum cultures made at the hospital were reviewed and those sputum cultures positive for bacteria were analyzed. Sputum specimens taken from intubated patients and specimens positive for acid-fast bacilli were excluded. Sputum samples were processed by Gram stain and culture. Only samples showing greater than 25 polymorphonuclear leukocytes and less than 10 squamous epithelial cells per low power field were cultured [7]. Cultures were performed on 5\% sheep's blood agar (oxoid ) and chocolate agar. The plates were incubated at $37^{\circ} \mathrm{C}$ for $24 \mathrm{~h}$ in a $5 \% \mathrm{CO}_{2}$ atmosphere. Bacteria isolated from sputum cultures were considered to be presumptive etiologic pathogens if they were compatible with the predominant organisms present on Gram stain and if cultured in abundant growth or pure growth. The isolated organisms were identified using a standard method [8]. Gram-negative aerobes were identified using the API 20 E (Analyta, Inc.)
Cases were classified into HAP (defined as positive sputum cultures taken more than $72 \mathrm{~h}$ after admission) and CAP (defined as positive sputum cultures taken less than $72 \mathrm{~h}$ after admission or those done on an outpatient basis). The following data were collected: patient's age, sex, nationality, and admission to intensive care unit (ICU). The type of organisms isolated, antibiotic susceptibility, use of empirical antibiotics, the presence of hypotension (defined as systolic pressure less than $90 \mathrm{~mm} \mathrm{Hg}$ and diastolic less than $60 \mathrm{~mm} \mathrm{Hg}$ ), tachycardia (pulse rate more than 120 beats per min), tachypnea (respiratory rate more than $30 / \mathrm{min}$ ), hypoxia $\left(\mathrm{P}_{\mathrm{O}_{2}}\right.$ less than $\left.10 \mathrm{kp}\right)$, a disturbed level of consciousness, a raised serum creatinine level during positive sputum culture, and outcome were recorded.

The in vitro antibacterial susceptibility of the bacteria isolated was determined by the disk diffusion method according to the guidelines of the National Committee for Clinical Laboratory Standards (NCCLS) [9]. Briefly, five representative colonies taken from the purity plates were suspended in sterile saline and diluted to a No. 0.5 McFarland turbidity standard. A sterile cotton swab dipped into this inoculum was used to streak Mueller-Hinton agar or Mueller-Hinton agar supplemented with 5\% sheep's blood and chocolate agar (Baltimore Biological Laboratories). The antibiotic disks were then applied onto the surface of the agar plates using a disk dispenser. The inoculated agar plates were then incubated at $37^{\circ} \mathrm{C}$ for $24 \mathrm{~h}$. After incubation the diameter of the zone of inhibition was measured and the results interpreted in accordance with the criteria recommended by the NCCLS. Statistical analysis was done using SPSS computer software; $p$ value $<0.05$ was considered significant.

\section{Results}

From a total of 11,069 patients greater than 14 years of age admitted to the hospital during the study period, 348 positive sputum cultures were recorded, making a rate of positive sputum culture of 31.4/1,000 admissions. Three hundred and twenty-four cases fulfilled the criteria and were included in the study. Almost $50 \%$ of them were Saudi. Two hundred and forty-eight of $324(77 \%)$ were hospital-acquired and 76 of 324 (23\%) were community-acquired with a mean age of 56.4 
Table 1. Type of organism in HAP and CAP

\begin{tabular}{|c|c|c|c|c|c|}
\hline \multirow[t]{2}{*}{ Type of organism } & \multicolumn{2}{|c|}{$\begin{array}{l}\text { HAP } \\
(\mathrm{n}=248)\end{array}$} & \multicolumn{2}{|c|}{$\begin{array}{l}\text { CAP } \\
(\mathrm{n}=76)\end{array}$} & \multirow[t]{2}{*}{ p value } \\
\hline & $\mathrm{n}$ & $\%$ & $\mathrm{n}$ & $\%$ & \\
\hline Streptococcus pneumoniae & 1 & 0.4 & 2 & 3 & 0.07 \\
\hline Staphylococcus aureus & 39 & 15 & 11 & 14 & 0.2 \\
\hline Haemophilus influenzae & 42 & 16 & 39 & 51 & $<0.001$ \\
\hline Moraxella catarrhalis & 14 & 5 & 8 & 11 & 0.07 \\
\hline Pseudomonas sp. & 74 & 29 & 7 & 9 & $<0.001$ \\
\hline Klebsiella spp. & 20 & 8 & 5 & 6 & 0.8 \\
\hline Proteus spp. & 1 & 0.4 & - & & - \\
\hline Enterobacter spp. & 19 & 8 & 1 & 1 & 0.07 \\
\hline Enterococci & 1 & 0.4 & - & & - \\
\hline Escherichia coli & 9 & 4 & - & & - \\
\hline Citrobacter spp. & 2 & 0.8 & - & & - \\
\hline Acinetobacter spp. & 10 & 4 & 2 & 3 & 0.7 \\
\hline Stentrophomonas maltophilia & 12 & 5 & 1 & 1 & 0.1 \\
\hline Others $^{1}$ & 4 & 2 & 1 & 1 & 0.8 \\
\hline
\end{tabular}

1 Streptococcus viridans, Serratia spp., group G streptococci. years (range $14-95$ years) and 49.8 years $(15-$ 102 years), respectively ( $\mathrm{p} 0.01$ ). The male sex predominated in both types of infection, 1.7:1 for hospital-acquired and 1.1:1 for community-acquired (p 0.08). As shown in table 1, Haemophilus influenzae, Moraxella catarrhalis and Streptococcus pneumoniae were isolated more in community-acquired infection while Pseudomonas sp. and Enterobacter sp. were isolated more in hospital-acquired infection. Pathogens isolated from the communityacquired infection were more susceptible to ampicillin, co-amoxiclav, ciprofloxacin, cefuroxime, tetracyclin and erythromycin while isolates of the hospital-acquired infection were more sensitive to gentamycin, amikacin, and imipenem as shown in table 2. Two hundred and ninety-two of $324(90 \%)$ were started on empirical antimicrobial agents. Mortality was significantly higher in hospitalacquired infections: 124 of $248(50 \%)$ versus 16 of $76(21 \%)(p<0.001)$. A more advanced age, tachycardia, hypotension, a disturbed level of consciousness, renal failure and ICU admission were factors associated with a poor outcome (table 3 ).

\section{Discussion}

A higher rate of HAP compared to CAP was found, which could be explained by the low probability of isolating the pathogens responsible for CAP. It has been reported that the pathogen has been identified in only $50 \%$ of the cases of CAP [1]. S. pneumoniae and atypical pathogens (i.e. Mycoplasma, Legionella sp., Chlamydia pneumoniae) can account for $30 \%$ of the cases of CAP $[2,10]$. Other pathogens include $H$. influenzae, Staphylococcus aureus, and M. catarrhalis [1115]. Our study showed that S. pneumoniae was isolated in only $3 \%$ of the cases of CAP while $H$. influenzae was the commonest 
Table 2. Antibiotic sensitivity of some isolates in CAP and HAP

\begin{tabular}{|c|c|c|c|c|c|}
\hline \multirow{3}{*}{$\begin{array}{l}\text { Antimicrobial } \\
\text { agents }\end{array}$} & \multicolumn{5}{|c|}{ Microorganisms } \\
\hline & \multicolumn{3}{|c|}{ community-acquired } & \multicolumn{2}{|l|}{ hospital-acquired } \\
\hline & $\begin{array}{l}\text { S. pneumoniae } \\
(\mathrm{n}=2)\end{array}$ & $\begin{array}{l}\text { H. influenzae } \\
(\mathrm{n}=39)\end{array}$ & $\begin{array}{l}\text { M. catarrhalis } \\
(\mathrm{n}=8)\end{array}$ & $\begin{array}{l}\text { Pseudomonas spp. } \\
(\mathrm{n}=74)\end{array}$ & $\begin{array}{l}\text { Enterobacter spp. } \\
(\mathrm{n}=19)\end{array}$ \\
\hline Penicillin & $1 \quad(50)$ & - & $2(26)$ & $1(2)$ & $6(31)$ \\
\hline Ampicillin & $2(100)$ & 28 (73) & $8(100)$ & 1 (2) & $1 \quad(6)$ \\
\hline Co-amoxiclav & $2(100)$ & $27 \quad(71)$ & - & $4(5)$ & $5(26)$ \\
\hline Ciprofloxacin & - & $32(54)$ & $8(100)$ & $53(72)$ & $13(68)$ \\
\hline Cefuroxime & $2(100)$ & $38(100)$ & $8(100)$ & $1(2)$ & $2(12)$ \\
\hline Erythromycin & $2(100)$ & $22 \quad(58)$ & $7 \quad(88)$ & $1(2)$ & $6(31)$ \\
\hline Tetracycline & $1(50)$ & 32 (84) & $7(75)$ & - & - \\
\hline Oxacillin & $2(100)$ & - & - & - & - \\
\hline Vancomycin & $2(100)$ & $1 \quad(3)$ & - & - & $1(6)$ \\
\hline Aztreonam & $1(50)$ & $18(48)$ & - & $47(63)$ & $5(26)$ \\
\hline Ceftazidime & - & - & - & $54(73)$ & $2(12)$ \\
\hline Ceftriaxone & $2(100)$ & $20 \quad(53)$ & $6 \quad(75)$ & $4(6)$ & $3(18)$ \\
\hline Gentamycin & $1(50)$ & $1 \quad(3)$ & - & $61(83)$ & $13(68)$ \\
\hline Amikacin & - & - & - & $64(86)$ & $13(68)$ \\
\hline Imipenem & - & (9) & - & $45(61)$ & $18(94)$ \\
\hline Piperacillin & - & - & - & $56(75)$ & $6(31)$ \\
\hline
\end{tabular}

Number and percent (in parentheses) are given.

Table 3. Relation of mortality to some variables

\begin{tabular}{lccc}
\hline Variable & $\begin{array}{l}\text { Dead } \\
(\mathrm{n}=141)\end{array}$ & $\begin{array}{l}\text { Alive } \\
(\mathrm{n}=183)\end{array}$ & $\mathrm{p}$ value \\
\hline Age, years & 59 & 52 & 0.003 \\
Sex (M:F) & $1.7: 1$ & $1.5: 1$ & 0.7 \\
Hypotension & $37(26)$ & $16(9)$ & $<0.001$ \\
Tachycardia & $59(42)$ & $56(31)$ & 0.04 \\
Tachypnea & $43(31)$ & $45(25)$ & 0.4 \\
Hypoxia & $57(40)$ & $60(33)$ & 0.1 \\
Disturbed consciousness & $70(50)$ & $15(8)$ & $<0.001$ \\
ICU admission & $107(76)$ & $47(26)$ & $<0.001$ \\
Renal failure & $74(52)$ & $27(15)$ & $<0.001$ \\
\hline \multicolumn{4}{c}{ Number and percent (in parentheses). } \\
\hline
\end{tabular}


cause, accounting for $51 \%$ of the cases, similar to that which had been reported from our hospital by Al Hadramy et al. [16] 10 years ago.

It has been reported that the proportion of hospitalized patients exhibiting the typical bacterial etiology ranges from 8 to $46 \%$ [17]. This wide range can be explained by the use of different methods of diagnosis and the use of antimicrobial agents at the time of specimen collection $[16,18]$. A high proportion of the patients studied were using antimicrobial agents at the time of specimen collection. The prevalence of atypical pathogens could not be identified in our study because the results of this study were reviewed retrospectively. According to the proceedings of the American Thoracic Society consensus conference [19], testing for atypical pathogens should be included in selected settings, which most probably were not encountered in our patients. However, testing for atypical pneumonia pathogens has been taken in consideration in a planned prospective study to assess their role in CAP of our hospitalized patients. Gram-negative bacilli are the commonest pathogens of HAP, a finding similar to that reported by others [20, 21]. The American Thoracic Society guidelines stress the use of empirical treatment as pathogen identification can be difficult [1]. We found that ampicillin, co-amoxiclav, fluoroquinolone, secondgeneration cephalosporin, erythromycin and tetracycline can be used empirically in the treatment of CAP, while aminoglycosides and imipenem can be used in HAP, a finding in agreement with the recommendations of others [1, 2, 15, 22-28]. Mortality from pneumonia (both CAP and HAP) has been reported to range from 10 to $70 \%[13,29-31]$, with a better prognosis for CAP than HAP [32], a finding similar to our own. Old age, hypotension, tachycardia, a disturbed level of consciousness, ICU admission and renal failure were found to be risk factors associated with high mortality, a finding also reported by Scott et al. [32] and others [10, 29, 33, 34].

\section{References}

1 Community acquired pneumonia: Outpatient treatment of patients 16 years and older. Institute for Clinical System Improvement. Postgrad Med 2000;107:246-253.

2 Bernstein JM: Treatment of community-acquired pneumonia: IDSA guidelines. Infectious Diseases Society of America. Chest 1999;115:9S$13 \mathrm{~S}$.

3 Freeman C, Nicolan DP: Community-acquired pneumonia in the long term care setting: The other community. Consult Pharm 1999;11:12591273.

4 Palmer CS, Zhan C, Elixhauser A, Halpern MT, Rance L, Feagan BG, Marrie TJ: Economic assessment of the community acquired pneumonia intervention trial employing levofloxacin. Clin Ther 2000;22:250264.
5 Fine MJ, Stone RA, Singer DE, Coley CM, Marrie TJ, Lave JR, Hough LJ, Obrosky DS, Schultz R, Ricci EM, Rogers JC, Kapoor WN: Processes and outcome of care for patients with community-acquired pneumonia: Results from the Pneumonia Patient Outcomes Research Team (PORT) cohort study. Arch Intern Med 1999;159:970-980.

6 Hospital-acquired pneumonia in adults: Diagnosis, assessment of severity, initial antimicrobial therapy, and preventive strategies. A consensus statement, American Thoracic Society, Nov 1995. Am J Respir Crit Care Med 1996;153:1711-1725.
7 Murray PR, Washington JA: Microscopic and bacteriologic analysis of expectorated sputum. Mayo Clin Proc 1975;50:339-344.

8 Murray PR, Baron EJ, Pfaller MA, Tenover FC, Yolder RH (ed): Manual of Clinical Microbiology. Washington, ASM Press, 1995.

9 National Committee for Clinical Laboratory Standards: Performance Standard for Microbial Susceptibility Testing (M100-S6). Villanova, NCCLS, 1995, vol 15, No 14.

10 Lange M: Community acquired pneumonia: An approach to antimicrobial therapy. Allergy Asthma Proc 2000;21:33-38.

11 Pozzi E: Community-acquired pneumonia: The ORIONE Board. Monaldi Arch Chest Dis 1999;54: 337-344. 
12 Ruiz M, Ewig S, Marcos MA, Martinez JA, Arancibia F, Mensa J, Torres A: Etiology of communityacquired pneumonia: Impact of age, comorbidity, and severity. Am J Respir Crit Care Med 1999;160: 397-405.

13 Ewig S, Torres A: Severe community-acquired pneumonia. Clin Chest Med 1999;20:575-587.

14 Sopena N, Sabria M, Pedro-Botet ML, Manterola JM Matas L, Dominguez J, Modol JM, Tudela P, Ausina V, Foz M: Prospective study of community acquired pneumonia of bacterial etiology in adults. Eur $\mathbf{J}$ Clin Microbiol Infect Dis 1999;18: 852-858.

15 Casellas JM, Gialardoni M, Tome G, Goldberg M, Ivanovic S, Orduna M, Dolmann A, Ascoli M, Ariza H, Montero JM: Comparative in vitro activity of levofloxacin against isolates of bacteria from adult patients with community-acquired lower respiratory tract infection. J Antimicrob Chemother 1999;43(suppl C): 37-42.

16 Al Hadramy MS, Altahawi AT, Shafi M: Acute lower respiratory tract infections in Jeddah. Saudi Med J 1988;9:34-39.

17 Mandell LA: Community-acquired pneumonia: Etiology, epidemiology and treatment. Chest 1995; 108(suppl 2):35-42.

18 Burman LA, Trollfors B, Andersson B, Henrichsen J, Juto P, Kallings I, Lagergard T, Mollby R, Norrby R: Diagnosis of pneumonia by cultures, bacterial and viral antigen detection tests and serology with special reference to antibodies against pneumococcal antigens. J Infect Dis 1991; 163:1087-1093.

19 Niederman MS, Bass JB, Campbell GD, Fein AM, Grossman RF, Mandell LA, Marrie TJ, Sarosi GA, Torres A, Yu VL: Guidelines for the initial management of adults with community-acquired pneumonia: Diagnosis, assessment of severity, and initial antimicrobial therapy. Am Rev Respir Dis 1993;148:14181426.
20 Medeiros EA: Treatment of pneumonia in hospitalized patients: Results of a multicenter study using a fourth generation cephalosporine. Rev Assoc Med Bras 1999;45:2-8.

21 Luo B, Huang Y, Qiu W, Wu ES: A prospective study on etiologic bacteria in 200 patients with pneumonia. Bull Huanan Med Univ 1998;23: 453-457.

22 Wunderink RG: Therapy for nosocomial pneumonia. Curr Opin Pulm Med 1997;3:120-124.

23 Quinn JP: Clinical strategies for serious infection: A North American perspective. Diagn Microbiol Infect Dis 1998;31:389-395.

24 Kashuba AD, Nafzieger AN, Drusano GL, Bertino JS Jr: Optimizing aminoglycoside therapy for nosocomial pneumonia caused by gramnegative bacteria. Antimicrob Agents Chemother 1999;43:623629.

25 Fluit AC, Schmitz FJ, Jones ME, Acar J, Gupta R, Verhoef J: Antimicrobial resistance among community acquired pneumonia isolates in Europe: First results from the SENTRY antimicrobial surveillance program 1997. SENTRY Participants Group. Int J Infect Dis 1999; 3:153-156.

26 Heffelfinger JD, Dowell SF, Jorgensen JH, Klugman KP, Mabry LR, Musher DM, Plouffe JF, Rakowsky A, Schuchat A, Whitney CG: Management of community acquired pneumonia in the era of pneumococcal resistance: A report from the Drug Resistance Streptococcus pneumoniae Therapeutic Working Group. Arch Intern Med 2000;160:1399-1408.

27 Jones RN, Croco MA, Kugler KC, Pfaller MA, Beach ML: Respiratory tract pathogens isolated from patients hospitalized with suspected pneumonia: Frequency of occurrence and antimicrobial susceptibility pattern from the SENTRY antimicrobial surveillance program. Diagn Microbiol Infect Dis 2003;37: 115-125.
28 Hoepelman IM, Mollers MJ, van Schie MH, Greefhorst AP, Schlosser NJ, Sinninghe Damste EJ, van de Moosdijk CN, Dalinghaus WH, Eland ME, Mol SJ, Rozenberg-Arska M: A short (3-day) course of azithromycin tablets versus 10-day course of amoxicillin-clavulanic acid (co-amoxiclav) in the treatment of adults with lower respiratory tract infections and effects on long-term, outcome. Int J Antimicrob Agents 1997;9:141-146.

29 Ewig S, Kleinfeld T, Bauer T, Seifert K, Schafer H, Goke N: Comparative validation of prognostic rules for community-acquired pneumonia in an elderly population. Eur Respir J 1999;14:370-375.

30 Vegelin AL, Bissumbhar P, Joore JC, Lammers JW, Hoepelman IM: Guidelines for severe communityacquired pneumonia in the western world. Neth J Med 1999;55:110 117.

31 Kobashi Y, Fujita K, Karino T, Yano T, Nakamura J, Okimoto N, Matsushima T, Soejima R: Clinical analysis of pneumonia in the elderly in a community hospital: Comparison of community-acquired pneumonia and nosocomial pneumonia. Kanseushogaku Zasshi 1999;73: 884-892.

32 Scott JA, Hall AJ, Muyodi C, Lowe B, Ross M, Chohan B, Mandaliya K, Getambu E, Glesson F, Drobniewski F, Marsh K: Aetiology, outcome and risk factors for mortality among adults with acute pneumonia in Kenya. Lancet 2000;355:1225-1230.

33 Garcia Ordonez MA, Alvarez Hurtado F, Cebrian Gallardo JJ, Lopez Gonzalez JJ, Franquelo Vega M, Martinez Gonzalez J, Juarez Fernandez C: Community-acquired bacteremic pneumonia in elderly. An Med Interna 1999;16:345-348.

34 Stebbings AE, Ti TY, Tan WC: Hospital acquired pneumonia in the medical intensive care unit: A prospective study. Singapore Med J 1999;40:508-512. 